SHORT COMMUNICATION

\author{
Sokoto Journal of Veterinary Scíences \\ (P-ISSN 1595-093X: E-ISSN 2315-6201) \\ http://dx.doi.org/10.4314/sokjvs.v18i4.7 \\ Bitrus et al. /Sokoto Journal of Veterinary Sciences, 18(4) : 226 - 229.
}

\title{
Occurrence and molecular detection of avian coronavirus in selected live bird markets, northwestern, Nigeria
}

\author{
I Bitrus, I Shittu*, CA Meseko \& TM Joannis \\ Regional Laboratory for Animal Influenza and other Transboundary Animal Diseases, National Veterinary \\ Research Institute, PMB 01 Vom, Plateau State, Nigeria
}

*Correspondence: Tel.: +2348035610703; E-mail: ismaila.shittu@gmail.com

\begin{abstract}
Copyright: (c) 2020
Bitrus et al. This is an open-access article published under the terms of the Creative Commons Attribution License which permits unrestricted use, distribution, and reproduction in any medium, provided the original author and source are credited.
\end{abstract}

Publication History: Received: 23-06-2020 Accepted: 06-10-2020

\begin{abstract}
Infectious bronchitis (IB) is one of the most common highly infectious viral respiratory diseases of poultry having wide geographical distribution. Yet, little is known about the infection in the northwestern states of Nigeria. In this study, a total of 263 pooled cloacal and tracheal swab samples were collected from apparently healthy avian species (duck, dove, geese, guinea fowl, local chicken, ostrich, parrot, pigeon, peacock, and turkey). The samples were from nine live bird markets in three states (Kaduna, Kano and Jigawa) of northwestern, Nigeria collected from September through November 2017. Total RNAs were extracted directly from the swab samples and screened for infectious bronchitis virus (IBV) using real-time reverse transcription-polymerase chain reaction. An overall prevalence of $38.0 \%(100 / 263)$ was recorded. IB was detected in $70 \%(7 / 10)$ of the avian species with prevalence of $100 \%$ in dove, local chicken $45.9 \%$, duck $42.3 \%$, geese $26.6 \%$, pigeon $23.5 \%$, turkey $20.0 \%$ and guinea fowl $6.2 \%$. Conversely, no detection was made from ostrich, parrot, and peacock. Widespread distribution of IBV was observed and evidence of subclinical infection in seven out of ten (70 \%) of the avian species sampled. These avian species harbouring IBV may act as reservoirs with an influence on the ecology and epidemiology of the disease. Continuous surveillance and characterization of the different serotypes in avian species are recommended to inform the adoption of suitable vaccination strategy and control measures for the disease in Nigeria.
\end{abstract}

Keywords: Infectious bronchitis virus, Live bird markets (LBMs), Molecular detection, Nigeria, Poultry

\section{Introduction}

Respiratory diseases are common occurrences in poultry production with accompanying complexity of causative agents involving both bacterial and viral pathogens (Shittu et al., 2019). One of the respiratory diseases, Infectious bronchitis (IB), mostly affects the respiratory tract, kidney, and reproductive system of chickens and other avian species (Jackwood \& de Wit, 2013). The common clinical signs of IB in affected birds include sneezing, coarse crackles, coughing, and reduction in feed intake. In layers, it causes a drop in egg production and quality resulting in fragile, misshapen shells and thin watery eggs (Shittu et al., 2019). In IB cases, mortalities may range from $20-30 \%$ due to concurrent infections with other opportunistic agents such as Escherichia coli, Mycoplasma gallisepticum and other viral respiratory agents (Jackwood \& de Wit, 2013; De Wit et al., 2011).

Infectious bronchitis has a wide geographical spread with presence in Africa, Asia, Australia, Europe, and the Americas. The causative agent, avian infectious bronchitis virus is a member of the genus Gammacoronavirus, subfamily orthocoronavirinae, 
family Coronaviridae, order Nidovirales (ICTV, 2019). The viral genome comprises a single-stranded positive-sense RNA having a size approximately 27.5 to $28 \mathrm{~Kb}$ which encodes four structural proteins that include- the spike, envelope, membrane, and nucleocapsid proteins (Jackwood \& de Wit, 2013). Many serotypes have been identified for IBV due to point mutations, genetic recombination events, and selective pressure in the hyper-variable regions of the genome (Jackwood \& de Wit, 2013). Several circulating serotypes of the virus which may not confer cross-protection on each other have been identified in poultry worldwide (Lin \& Chen, 2017). As new strains of IBV continue to emerge, rapid detection is useful for the implementation of control measures, research purposes, and understanding the epidemiology and evolution of the virus (De Wit, 2000). For IBV detection, molecular assays, such as reverse transcriptase-polymerase chain reaction (RT$P(R)$, are commonly used. The assay is highly specific and sensitive with results obtained in a short time. Molecular assays can detect viral RNA directly from a clinical sample or from a virus propagated in embryonated chicken eggs (ECE) (Acevedo et al., 2013; Alp Onen \& Ozgur, 2017).

In Nigeria, Adene \& Ojo (1976) described and documented the first evidence of suspected IB disease. Previous data on IBV in Nigeria focused on seroprevalence (Emikpe et al., 2010; Mungadi et al., 2015). There is limited information on IB seroprevalence and serotypes in the northwestern region of Nigeria. This study was designed to detect IBV from different species of apparently healthy birds from selected live bird markets (LBMs) in the northwestern Nigeria.

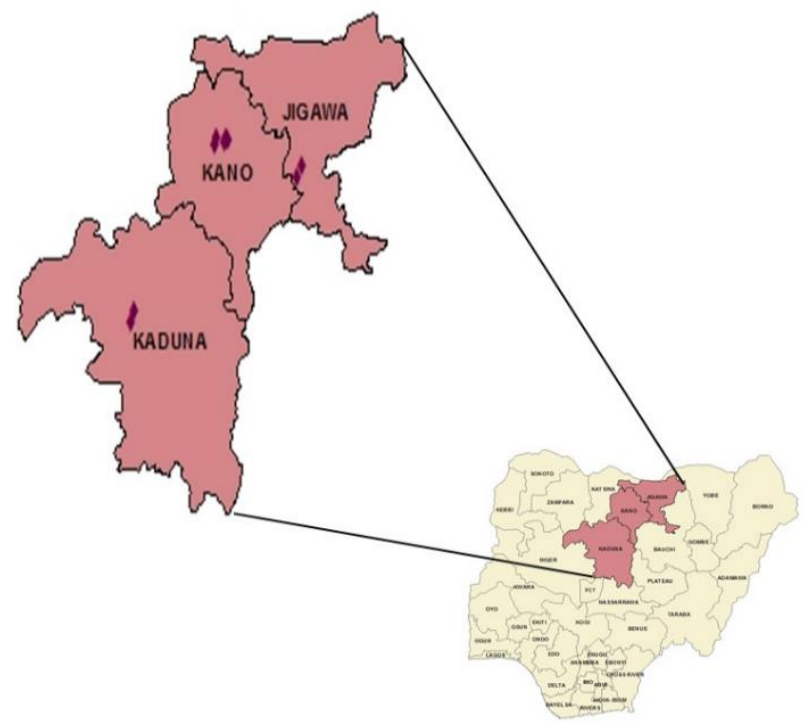

Figure 1: Map of Nigeria showing the States where samples were collected for the study

\section{Materials and Methods}

A descriptive cross-sectional study was conducted between September to November, 2017 in nine LBMs across three northwestern states; Kaduna $(\mathrm{N}=2)$, Kano ( $\mathrm{N}=5)$ and Jigawa $(\mathrm{N}=2)$ (Table 1; Figure 1) of Nigeria. Prior to sampling, authorization was received from Institutional Animal Care and Use Committee. In all, a total of 263 pooled tracheal and cloacal swabs were collected in a virus transport medium (VTM) from 10 different avian species: duck, dove, geese, guinea fowl, local chicken, ostrich, parrot, pigeon, peacock, and turkey (Table 2). The samples in VTM were transported in a cold box with ice to the Regional laboratory for Animal Influenza and Newcastle Disease, National Veterinary Research Institute, Vom for analysis. Swabs originating from the same epidemiological units (cage(s) in a store with same species) were pooled (up to 3-5 swabs/pool) into Eppendorf tubes (1.5ml capacity) and stored at $-80^{\circ} \mathrm{C}$ until tested.

Total RNA was extracted from the pooled swab samples using QIAmp viral RNA mini kit (QIAGEN, Germany). IBV vaccine and nuclease free water were used as positive and negative controls, respectively. Each RNA sample was eluted in $60 \mu$ l elution buffer according to the manufacturer's instructions and stored at $-80^{\circ} \mathrm{C}$ for later use. To detect IBV from the samples, a generic RT-qPCR that targets the $5^{\prime}$ UTR gene in the IBV genome was performed using QuantiTect Multiplex RT-PCR Kit (Qiagen, Germany) as previously reported (Callison et al., 2006). The RTqPCR amplification was performed using RotorGene $Q$ (Qiagen Co., Hilden, Germany) system with the

following thermal cycling profile: $50{ }^{\circ} \mathrm{C}$ for $30 \mathrm{~min}$ for $\mathrm{RT}$ reaction, initial denaturation at $95{ }^{\circ} \mathrm{C}$ for 15 min, followed by 40 cycles at $94{ }^{\circ} \mathrm{C}$ for $10 \mathrm{sec}$ denaturation and $60{ }^{\circ} \mathrm{C}$ at $60 \mathrm{sec}$. annealing and data collection. The cycle threshold $(\mathrm{Ct})$ number was determined corresponding to the PCR cycle number for each reaction.

\section{Results and Discussion}

Overall, a prevalence of $38.0 \%(100 / 263)$ was recorded (Table 1). State-specific prevalence for IBV was $40.0 \%(20 / 50), 16.4 \%$ (9/55), and $44.9 \%$ (71/158) for Kaduna, Kano, and Jigawa states respectively (Table 1). At specie level, IBV prevalence of $100 \%$ (3/3) dove, 45.9\% (28/61) local chicken, 42.3\% (58/137) duck, $26.6 \%$ (4/15) geese, $23.5 \%$ (4/17), pigeon, $20.0 \%$ (2/10), turkey, 2 and $6.2 \%(1 / 16)$ guinea fowl respectively, was recorded (Table 2). IBV genetic material was not detected 
Table 1. Sample distribution and prevalence of IBV in some selected LBMs across 3 states

\begin{tabular}{|c|c|c|c|}
\hline State & Live Bird Markets & Number sampled & Number positive \\
\hline Kaduna & $\begin{array}{l}\text { Igabi } \\
\text { Kaduna North central }\end{array}$ & 50 & $20(40.0 \%)$ \\
\hline \multirow{5}{*}{ Kano } & Kurmi & \multirow{5}{*}{55} & \multirow{5}{*}{9 (16.4\%) } \\
\hline & Fagge & & \\
\hline & Janguza & & \\
\hline & Sabon Gari & & \\
\hline & Sharada & & \\
\hline \multirow[t]{2}{*}{ Jigawa } & Dutse & \multirow{2}{*}{158} & \multirow{2}{*}{71 (44.9\%) } \\
\hline & Kiyawa/Shuwarin & & \\
\hline
\end{tabular}

from the ostrich, parrot, and peacock samples. Variations in prevalence may be attributed to the different sample sizes collected from the states and species in the study areas. This study established molecular detection of IBV in seven out of ten $(70 \%, 7 / 10)$ different species of birds sampled (Table 2). This confirms the widespread circulation of the virus and its ability to replicate in other avian specie apart from chickens without showing Table 2: IBV result of different avian species from selected LBMs from 3 states Species of Number of samples Number positive Number Bird $\quad(\mathrm{Ct}<35) \quad$ negative clinical signs (Cavanagh et al., 2002). The detection of IBV

gene in some of the apparently healthy birds sampled from the selected LBMs with no history of vaccination against IB may suggest natural exposure to IBV. Hence, these birds could serve as reservoirs shedding the virus into the surroundings and playing a significant role in the epidemiology of the disease (Adebiyi \& Fagbohun, 2017). In most instances, avian coronavirus from one specie has been shown to replicate in other avian species without observable clinical signs (Ismail et al., 2003). The detection of IBV in other species other than the chickens in this study is in agreement with previous reports of De Wit et al. (2011) who detected IBV infection in ducks, turkeys, pigeons, quails and geese. More so, in this study, IBV was detected in local chickens $(28 / 61$, $45.9 \%)$ and guinea fowl $(1 / 16,6.2 \%)$ (Table 2), contrary to the report by Ayim-Akonor et al. (2018) that reported no detection of IBV in both local chickens and guinea fowls by conventional RT-PCR. The variation might be due to the sensitivity of the different molecular techniques used. The increased sensitivity of RT-qPCR compared to the conventional RT-PCR might be due to detection of the fluorescent signal emitted by specific amplification products
(Acevedo et al., 2013). The RT-qPCR assay targeting the highly conserved $5^{\prime} /$ UTR gene have greater sensitivity than conventional RT-PCR in detecting IBV nucleic acids (Acevedo et al., 2013). This study has also shown that direct sampling from cloacal and tracheal swab samples is sufficient for IBV detection. This is in agreement with earlier report by Alp Onen \& Ozgur (2017), who obtained positive signals by RTqPCR using viral RNA directly from VTM. In some previous studies, the virus was cultured in ECE before the RT-qPCR (Lee \& Jackwood, 2000). This might be the reason for the high threshold cycle (Ct $>35)$ recorded for $61.97 \%(163 / 263)$ of the samples analysed in this study (Table 2), as swabs samples were not inoculated in ECE before extraction. Using IBV RNAs extracted from allantoic fluid harvest for RT-PCR procedure has been shown to be very efficient for detection and identification of IBV serotypes (Meulemans et al., 2001).

In conclusions, our findings established widespread IBV circulation in different species of birds from selected LBM in three states of northwestern region of Nigeria, using the most sensitive molecular detection technique. We therefore recommend 
further studies focusing on surveillance, virus isolation, and identification of the prevalent serotypes so as to adopt suitable vaccination strategy and other control measures for the disease in this region and Nigeria at large.

\section{Conflict of interest}

The authors declare no conflict of interest.

\section{References}

Acevedo AM, Perera CL, Vega A, Ríos L, Coronado L, Relova D, Frías MT, Ganges L, Núñez JI \& Pérez LJ (2013). A duplex SYBR Green I-based real-time RT-PCR assay for the simultaneous detection and differentiation of Massachusetts and non-Massachusetts serotypes of infectious bronchitis virus. Molecular and Cellular Probes, 27(5-6): 184192.

Adebiyi Al \& Fagbohun AF (2017). Infectious Bronchitis Virus in Captured Free-Living, Free-Range and Intensively Reared Birds in Southwest Nigeria. Folia Veterinaria, 61(1): 23-26.

Adene DF \& Ojo MO (1976). A preliminary report on infectious bronchitis of chickens in Nigeria. Journal of Nigeria Veterinary Medical Association, 5(1): 68-69.

Alp Onen E \& Ozgur Y (2017). Investigation of Infectious bronchitis virus strains by real time RT-PCR and S1 gene sequencing in broilers. Journal of Veterinary Science \& Medical Diagnosis, doi.10.4172/23259590.1000243

Ayim-Akonor M, Owusu-Ntumy D Dela, Ohene-Asa $\mathrm{HE}$, Oduro-Abrokwa A, Hammond $P$, Appenteng M \& Annan D (2018). Serological and molecular surveillance of infectious bronchitis virus infection in free-range chickens and guinea fowls in the Ga-East district of Ghana. Journal of Veterinary Medicine, 1-6. doi.10.1155/2018/4949580.

Callison SA, Hilt DA, Boynton TO, Sample BF, Robison R, Swayne DE \& Jackwood MW (2006). Development and evaluation of a real-time Taqman RT-PCR assay for the detection of infectious bronchitis virus from infected chickens. Journal of Virological Methods, 138(1-2): 60-65.

Cavanagh D, Mawditt K, Welchman DB, Britton P \& Gough RE (2002). Coronaviruses from pheasants (Phasianus colchicus) are genetically closely related to coronaviruses of domestic fowl (infectious bronchitis virus) and turkeys. Avian Pathology, 31(1): 81-93.

De Wit JJ (2000). Detection of infectious bronchitis virus. Avian Pathology, 29(2): 71-93.

De Wit JJ, Cook JKA \& van der Heijden HMJF (2011). Infectious bronchitis virus variants: A review of the history, current situation and control measures. Avian Pathology, 40(3): 223-235.

Emikpe BO, Ohore OG, Olujonwo M, \& Akpavi SO (2010). Prevalence of antibodies to Infectious Bronchitis Virus (IBV) in chickens in Southwestern Nigeria. African Journal of Microbiological Research, 4(1): 92-95.

International Committee on Taxonomy of Virus (2019). Viruses". https://talk.ictvonline.org/taxonomy/p/tax onomy-history?taxnode id=201901880, retrieved 16-01-2020.

Ismail MM, Tang Y \& Saif YM (2003). Pathogenicity of turkey coronavirus in turkeys and chickens. Avian Diseases, 47(3): 515-522.

Jackwood MW \& de Wit S (2013). Infectious Bronchitis. Diseases of Poultry, doi.10.1002/9781119421481.ch4

Lee C-WW \& Jackwood MW (2000). Evidence of genetic diversity generated by recombination among avian coronavirus IBV. Archives of Virology, 145(10): 21352148.

Lin S-Y \& Chen H-W (2017). Infectious Bronchitis Virus Variants: Molecular analysis and pathogenicity investigation. International Journal of Molecular Sciences, 18(10): 2030 doi.10.3390/ijms18102030.

Meulemans G, Boschmans $M$, Decaesstecker $M$, van den Berg TP, Denis P \& Cavanagh D (2001). Epidemiology of infectious bronchitis virus in Belgian broilers: A retrospective study, 1986 to 1995. Avian Pathology, 30(4): 411-421.

Mungadi HU, Mera UM, Adamu YA, Musa U \& Achia CR (2015). Sero-prevalence of infectious bronchitis antibodies in local chickens in live bird markets in Sokoto State, Nigeria. Scientific Journal of Biological Sciences 4(7) 53-56.

Shittu I, Gado DA, Meseko CA, Nyam DC, Olawuyi KA, Moses GD, Chinyere $C N$ \& Joannis $T M$ (2019). Occurrence of infectious bronchitis in layer birds in Plateau state, north central Nigeria. Open Veterinary Journal, 9(1): 7480. 